\title{
13. SILICEOUS SPONGE SPICULES, SILICOFLAGELLATES, AND EBRIDIANS FROM HOLE 918D, CONTINENTAL RISE OF THE GREENLAND MARGIN ${ }^{1}$
}

\author{
L. Kirk Lurvey, ${ }^{2,3}$ Kevin McCartney, ${ }^{2}$ and Wuchang $\mathrm{Wei}^{4}$
}

\begin{abstract}
Sediments recovered from Hole 918D on the continental rise of the Greenland Margin were found to contain siliceous sponge spicules, silicoflagellates, and ebridians. An extreme fossil-barren interval occurred in lower Miocene and upper Miocene sediments of the core, with sponge spicules occurring in the middle Miocene. Though generally rare, the sponge spicules were morphologically diverse, with monaxons being the most abundant. Other morphologies and an undescribed spicule type were found. Representatives of several silicoflagellate genera were found in a narrow horizon of the upper Pliocene. The silicoflagellates were of a variety of ages, showing that this layer has been reworked. This interval also included two large ebridians, Triskelion gorgon and Adonnadonna primadonna, that have not been previously described from the North Atlantic.
\end{abstract}

\section{INTRODUCTION}

Ocean Drilling Program (ODP) Leg 152 recovered sediment samples from six sites off the Greenland coast in order to study the rift volcanism and history of glaciation of the area. These sites were on a northwest-southeast transect across the East Greenland Margin, approximately $130 \mathrm{~km}$ from the Greenland coast near the center of a seaward-dipping reflector sequence (SDRS) (Fig. 1).

A diverse assemblage of siliceous sponge spicules were found in middle Miocene sediments from Site 918D. The spicules were not generally abundant but were well preserved. The assemblage was dominated by monaxons with other spicule morphologies representing a fraction of total spicule abundance. The abundance and diversity of sponge spicules at Hole 918D are tabulated in this study (Table 1).

Sponge spicules from deep ocean sediments have been studied infrequently. The results of this study can be compared to those of McCartney (1987, 1990), Ahlbach and McCartney (1992) and Zolnik et al., (1992); see McCartney (1990) for a tabulation of other sponge spicule literature from deep ocean studies. These studies show a generally similar diversity, with monaxons being the predominant spicule group. Palmer (1988) and Ivanik (1983) found abundant tetraxonal and triaxonal spicules and used their relative abundances to make paleobathymetric interpretations, but these spicule types were not abundant in this study.

\section{METHODS}

Raw samples were processed by disaggregating the sediment samples in $100-\mathrm{mL}$ beakers after which $\mathrm{H}_{2} \mathrm{O}_{2}$ and $10 \% \mathrm{HCl}$ solutions were added. The beakers were then heated for $3-4 \mathrm{hr}$ on a hot plate. The remaining solutions were placed in test tubes and centrifuged and decanted three times. Smear slides were made from the remaining sediments using Canada balsam and $22 \mathrm{~mm} \times 50 \mathrm{~mm}$ coverslips.

${ }^{1}$ Saunders, A.D., Larsen, H.C., and Wise, S.W., Jr. (Eds.), 1998. Proc. ODP, Sci. Results, 152: College Station, TX (Ocean Drilling Program).

${ }^{2}$ Micropaleontology Undergraduate Research Laboratory, University of Maine at Presque Isle, Presque Isle, ME 04769, U.S.A. Correspondence author: McCartney@ polaris.umpi.maine.edu

${ }^{3}$ Department of Geology, University of Maine, Orono, ME 04469, U.S.A.

${ }^{4}$ Scripps Institution of Oceanography, University of California at San Diego, La Jolla, CA 92093-0215, U.S.A.
Investigations were made using an Olympus BH-2 light microscope with a $20 \times$ objective. The entire coverslip was examined and absolute counts of specimens were recorded. In the event that no specimens were found on half of the coverslip, the rest was not investigated. In the narrow horizon where silicoflagellates and ebridians were present, extra slides were made and examined to increase specimen counts. The abundance of specimens was recorded in absolute counts, with pieces representing over half of the specimen, or enough to allow identification, counted as one.

\section{SITE SUMMARY}

Site $918 \mathrm{D}\left(63^{\circ} 5.572^{\prime} \mathrm{N}, 38^{\circ} 38.334^{\prime} \mathrm{W}\right.$; water depth $\left.1868.2 \mathrm{~m}\right)$ was drilled on the upper continental rise and has a thick Quaternary section. The site was selected to determine the age and subsidence history of the SDRS, the oceanographic history of the Irminger Basin, and the history of glaciation in southern Greenland. The core from Hole $918 \mathrm{D}$ provides the most complete sedimentary record recovered in the North Atlantic.

Sponge spicules were found to be sparse in an 80-m interval of the middle Miocene and rare or absent elsewhere in the core. The sponge spicule-bearing interval is in lithologic Unit II, which is a silt with varying amounts of nannofossils and clay. The sponge spicules were always present in this interval but their numbers never exceeded 31 specimens in a slide.

Silicoflagellates and ebridians were only found in two samples; all but one of the observed specimens came from Sample 152-918D13R-1, 93-94 cm. This sample is from lithologic Subunit ID, which is a silt with dropstones.

\section{SPONGE SPICULES}

Sponges have an internal skeleton of spicules that may be of calcareous or siliceous composition. Various spicule shapes and sizes have been used to classify poriferans taxonomically (Ehrenberg, 1854). However, a single living sponge may contain a variety of spicule types. A descriptive terminology has been used to classify sponge spicules in recent literature (Bukry, 1978; Palmer, 1988; Ahlbach and McCartney, 1992), and is used in this study. Various types of sponge spicules are described here including monaxons, which have a skeletal element with a single axis; polyaxons, which have many equal-sized rays radiating from a single central point; and triaxons, which are spicules with three axes. 


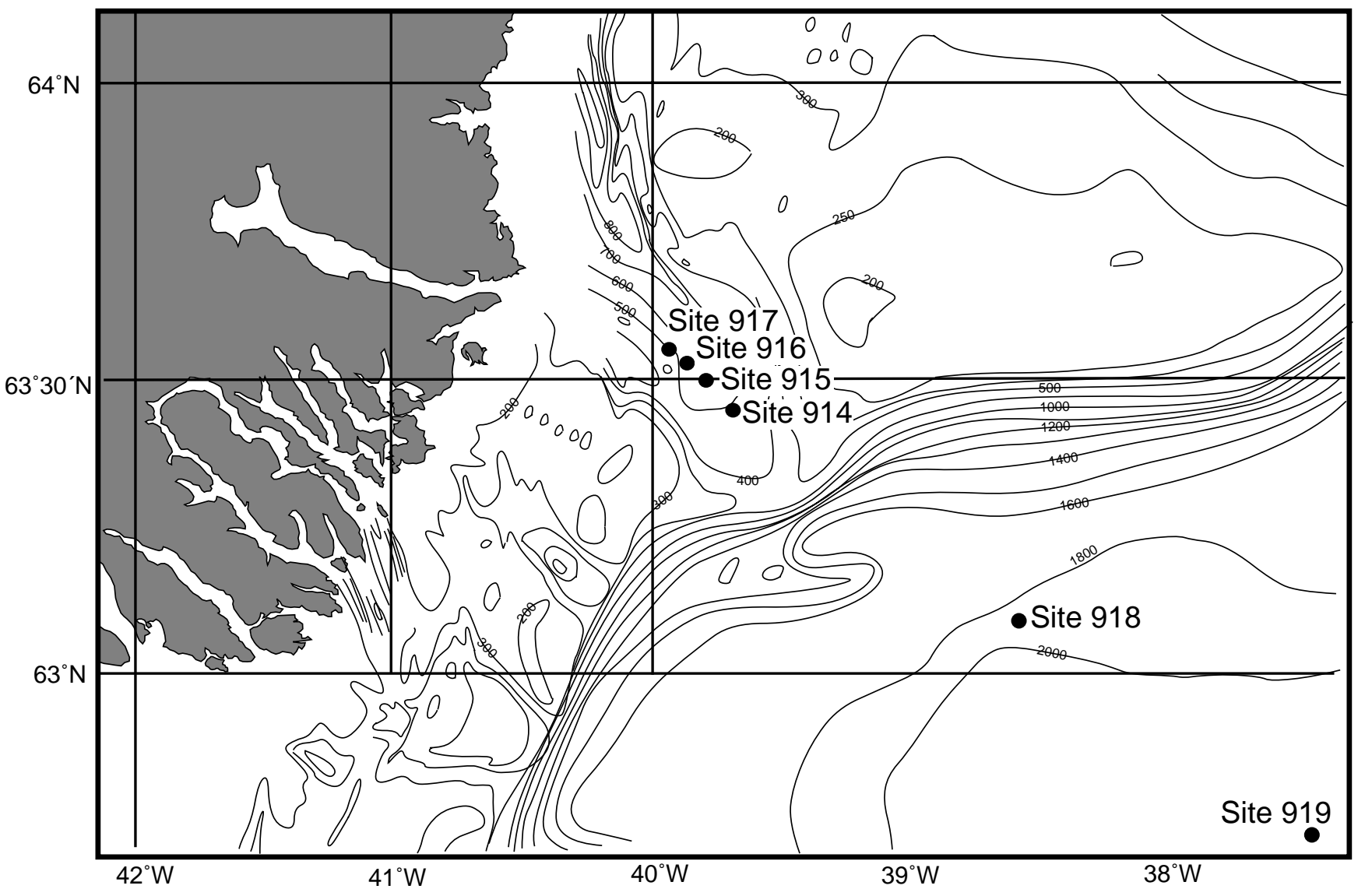

Figure 1. Location map of sites drilled during Leg 152.

\section{Monaxons \\ Diactinal (monaxons with similar ends)}

Oxeas (monaxon with both ends tapering to a point; Pl. 1, Figs. 1, 2, 57.): Oxeas were the predominant spicule type found throughout the samples from Hole 918D. Short, thick oxeas are included in this grouping, which differ from the separate tabulation used by McCartney (1987). Many nearly identical, slightly curved oxea (Pl. 1, Figs. 1, 5) were found that were similar to those found by Hartman (1982), where they are called Haliclona sp. The oxeas showed a wide variability and several interesting variations were noted; one unusual oxea had a tiny bulb at the tip (Pl. 1, Fig. 7; see Hartman, 1982, fig. 16-13. g, for a similar specimen.)

Acanthoxeas (spinose oxeas; Pl. 1, Figs. 3, 4): These monaxons varied in length from $30 \mu \mathrm{m}$ to $60 \mu \mathrm{m}$. The spines were generally distinct and spread over the entire length of the spicule.

Strongyles (monaxons with both ends rounded; for photo, see McCartney 1987, pl. 1, fig. 5): Strongyles were very rare throughout the samples.

Acanthostrongyles (spinose strongyles; Pl. 1, Fig. 3): Sample 152-918D$14 \mathrm{R}-1,109-110 \mathrm{~cm}$, contained a single specimen that was an acanthostrongyle. The spines were arranged evenly across the specimens.

\section{Monactinal (monaxons with one round end and one pointed end)}

Styles (no change in thickness at rounded end): Many styles were noted (see McCartney, 1987, pl. 1, fig. 2, for characteristic form). An unusual style with a bulbous entral region was found in Sample 152-918D-39R-1, 78-79 $\mathrm{cm}$ (Pl. 1, Figs. 6, 7). This is referred to here as a centrotylote style. Hartman (1982) noted a similar feature in an oxea belonging to Plakina sp.

Acanthostyles (spinose styles): Similar specimens to those found in this study are illustrated by McCartney (1987; pl. 1, fig 4).

Tylostyles (one pointed end and one knobbed end; Pl. 1, Fig. 8): Typical specimens found in this study were similar to those illustrated by McCartney (1987, pl. 2, fig 7; 1990, pl. 2, fig. 6). An unusual example (Pl. 1, Fig. 8) with a bent bulbous termination was found in Sample 152-918D-41R-3, 120-121 $\mathrm{cm}$.

Acanthotylostyles (spinose tylostyles; Pl. 1, Figs. 9, 10): This type was rare throughout the spicule-bearing interval.

Sinusoidal-spicules (spicules with sinusoid curvature; Pl. 2, Fig. 9): Similar spicules have been illustrated by Bukry (1978, pl. 14, fig. 7), McCartney (1987, pl. 2, fig. 10) and Locker and Martini (1986, pl. 13, fig. 3). The abundance in this study (five specimens) appears to be unusually high compared with the previous work.

Isochelae (curved bar-bearing shovel-like shaped ends of similar size; Pl. 2, Figs. 4-6): Isochelae occurred sparsely throughout the interval. A well-preserved cluster of isochela was found in Sample 152-918D-41R-2, 9-10 cm.

\section{Polyaxons}

Spherasters (conical rays emanating from a spherical center; Pl. 2, Fig. 10): Oxyasters (thin, pointed rays; Pl. 2, Fig. 11) were included within this group.

Streptasters (spines radiate from various points along a straight or twisted axis; Pl. 2, Fig. 8): These were very rare throughout the samples.

\section{Triaxons}

Triods (three rays of equal size; Pl. 2, Fig. 7): Triods were rare throughout the spicule-bearing interval.

Hexactines (six rays nearly perpendicular to each other): Two specimens of this morphology were found.

\section{Miscellaneous Spicules}

Amphidiscs (both ends expanded in umbrella-like fashion): A single amphidisc with an anchorate termination similar to one illustrated by McCartney (1987, pl. 3, fig. 6) was found in Sample 152-918B-39R-3, 93-94 cm. 
Table 1. Abundance of siliceous sponge spicules, silicoflagellates, and ebridians from Hole 918D.

\begin{tabular}{|c|c|c|c|c|c|c|c|c|c|c|c|c|c|c|c|c|c|c|c|c|c|c|c|c|c|}
\hline \multirow[b]{2}{*}{ Epoch } & \multirow[b]{2}{*}{$\begin{array}{l}\text { Core, section, } \\
\text { interval }(\mathrm{cm})\end{array}$} & \multirow[b]{2}{*}{$\begin{array}{l}\text { Depth } \\
\text { (mbsf) }\end{array}$} & \multirow[b]{2}{*}{ 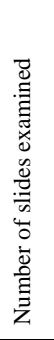 } & \multicolumn{15}{|c|}{ Sponge Spicules } & & \multicolumn{3}{|c|}{ Silicoflagellates } & \multicolumn{3}{|c|}{ Ebridians } \\
\hline & & & & 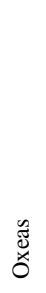 & 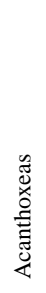 & 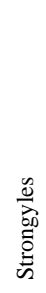 & 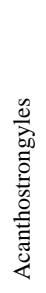 & $\frac{0}{2}$ & 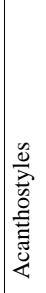 & 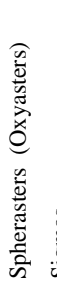 & 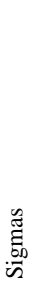 & & & 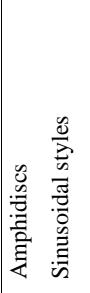 & 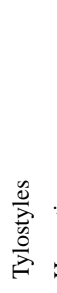 & 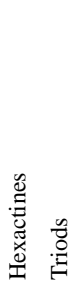 & 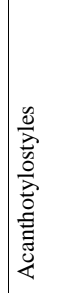 & 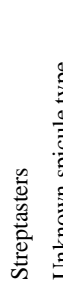 & & 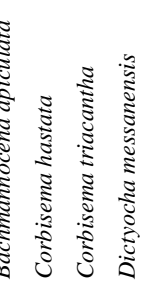 & 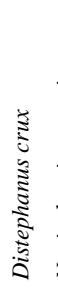 & 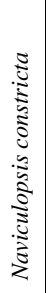 & 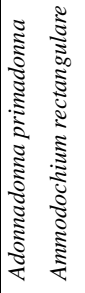 & 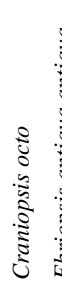 & 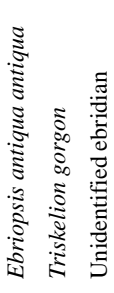 \\
\hline $\begin{array}{c}\text { early } \\
\text { Pliocene }\end{array}$ & \begin{tabular}{|} 
152-918D- \\
$11 \mathrm{R}-1,62-63$ \\
$13 \mathrm{R}-1,93-94$ \\
$14 \mathrm{R}-1,109-110$ \\
18R-1, 61-62 \\
22R-3, 65-67
\end{tabular} & $\begin{array}{l}386.7 \\
404.8 \\
413.9 \\
448.8 \\
487.5\end{array}$ & $\begin{array}{l}0.5 \\
2.0 \\
0.5 \\
0.5 \\
0.5\end{array}$ & & & & 1 & & & & & & & & & & & & & $\begin{array}{llll}2 & 2 & 1 & 1\end{array}$ & 12 & 4 & 16 & 2 & $\begin{array}{lll}1 & 8 & 3\end{array}$ \\
\hline $\begin{array}{c}\text { late } \\
\text { Miocene }\end{array}$ & $\begin{array}{l}24 \mathrm{R}-1,61-62 \\
25 \mathrm{R}-1,63-64 \\
27 \mathrm{R}-1,66-67 \\
28 \mathrm{R}-1,67-68 \\
\text { 29R-1, 67-68 } \\
\text { 31R-1, 64-65 } \\
\text { 32R-1, 65-66 } \\
33 \mathrm{R}-1,59-60 \\
34 \mathrm{R}-1,78-79 \\
35 \mathrm{R}-1,33-34 \\
36 \mathrm{R}-1,74-75 \\
\text { 37R-1, 34-35 }\end{array}$ & $\begin{array}{l}503.8 \\
513.4 \\
532.8 \\
542.5 \\
552.1 \\
571.3 \\
581.0 \\
550.6 \\
600.4 \\
609.5 \\
619.6 \\
628.9\end{array}$ & $\begin{array}{l}0.5 \\
0.5 \\
0.5 \\
0.5 \\
0.5 \\
0.5 \\
0.5 \\
0.5 \\
0.5 \\
0.5 \\
0.5 \\
0.5\end{array}$ & & & & & & & & & & & & & & & & & & & & & & \\
\hline $\begin{array}{l}\text { middle } \\
\text { Miocene }\end{array}$ & $\begin{array}{l}38 \mathrm{R}-1,59-60 \\
38 \mathrm{R}-3,62-63 \\
38 \mathrm{R}-4,17-18 \\
38 \mathrm{R}-5,15-16 \\
39 \mathrm{R}-1,78-79 \\
39 \mathrm{R}-2,95-96 \\
39 \mathrm{R}-3,93-94 \\
39 \mathrm{R}-4,18-19 \\
39 \mathrm{R}-5,80-81 \\
40 \mathrm{R}-2,41-42 \\
40 \mathrm{R}-3,33-34 \\
40 \mathrm{R}-4,50-51 \\
40 \mathrm{R}-5,53-64 \\
41 \mathrm{R}-1,91-92 \\
41 \mathrm{R}-2,9-10 \\
41 \mathrm{R}-3,120-121 \\
41 \mathrm{R}-4,109-110 \\
41 \mathrm{R}-5,70-71 \\
42 \mathrm{R}-1,71-72 \\
42 \mathrm{R}-2,65-66 \\
42 \mathrm{R}-3,54-55 \\
42 \mathrm{R}-4,63-64 \\
42 \mathrm{R}-5,96-97 \\
43 \mathrm{R}-1,72-73 \\
43 \mathrm{R}-2,52-53 \\
44 \mathrm{R}-1,61-63 \\
44 \mathrm{R}-3,64-65 \\
44 \mathrm{R}-4,66-67 \\
47 \mathrm{R}-2,66-67\end{array}$ & $\begin{array}{l}638.8 \\
641.8 \\
642.9 \\
644.4 \\
648.7 \\
650.4 \\
651.8 \\
652.6 \\
65.7 \\
659.4 \\
660.8 \\
662.5 \\
664.1 \\
668.1 \\
668.8 \\
671.4 \\
672.8 \\
673.9 \\
677.5 \\
678.9 \\
680.3 \\
681.9 \\
683.8 \\
687.1 \\
688.5 \\
696.7 \\
699.7 \\
701.8 \\
726.8\end{array}$ & $\begin{array}{l}0.5 \\
0.5 \\
0.5 \\
0.5 \\
1.0 \\
1.0 \\
1.0 \\
1.0 \\
1.0 \\
0.5 \\
1.0 \\
1.0 \\
1.0 \\
1.0 \\
1.0 \\
1.0 \\
1.0 \\
1.0 \\
1.0 \\
1.0 \\
1.0 \\
1.0 \\
1.0 \\
1.0 \\
1.0 \\
1.0 \\
1.0 \\
1.0 \\
0.5\end{array}$ & $\begin{array}{r}15 \\
14 \\
5 \\
7 \\
4 \\
1 \\
11 \\
18 \\
11 \\
3 \\
13 \\
10 \\
10 \\
8 \\
3 \\
6 \\
16 \\
1 \\
20 \\
2 \\
5 \\
8 \\
2 \\
6 \\
1\end{array}$ & $\begin{array}{l}1 \\
2 \\
4 \\
2 \\
1 \\
1 \\
1 \\
1 \\
1 \\
1 \\
1 \\
3 \\
1 \\
1 \\
1\end{array}$ & $\begin{array}{l}1 \\
4\end{array}$ & $\begin{array}{l}1 \\
1\end{array}$ & $\begin{array}{l}2 \\
1 \\
1\end{array}$ & $\begin{array}{l}1 \\
1 \\
1\end{array}$ & $\begin{array}{l}1 \\
\\
1 \\
1 \\
3 \\
4 \\
1 \\
1 \\
1 \\
1 \\
5 \\
1 \\
4 \\
1 \\
1 \\
2\end{array}$ & $\begin{array}{l}1 \\
1 \\
1\end{array}$ & $\begin{array}{l}2 \\
3 \\
1 \\
1 \\
1 \\
1 \\
2\end{array}$ & 1 & $\begin{array}{l}2 \\
1 \\
1 \\
1\end{array}$ & $\begin{array}{l}1 \\
3 \\
1 \\
3 \\
1 \\
2 \\
1 \\
1\end{array}$ & $\begin{array}{ll} & 1 \\
1 & \\
& \\
& \\
& \\
1 & \end{array}$ & \begin{tabular}{|l}
1 \\
1 \\
\\
1 \\
\\
5 \\
1 \\
1 \\
1
\end{tabular} & $\begin{array}{l} \\
1 \\
1\end{array}$ & & & 1 & & & & \\
\hline $\begin{array}{c}\text { early } \\
\text { Miocene }\end{array}$ & $\begin{array}{l}51 \mathrm{R}-2,21-52 \\
51 \mathrm{R}-4,28-29 \\
52 \mathrm{R}-1,74-75 \\
52 \mathrm{R}-4,91-92 \\
53 \mathrm{R}-1,38-39 \\
53 \mathrm{R}-4,77-78 \\
55 \mathrm{R}-1,38-39 \\
55 \mathrm{R}-4,74-75 \\
57 \mathrm{R}-1,87-88\end{array}$ & $\begin{array}{l}765.2 \\
768.0 \\
773.6 \\
778.3 \\
782.9 \\
787.8 \\
802.2 \\
807.0 \\
821.9\end{array}$ & $\begin{array}{l}0.5 \\
0.5 \\
0.5 \\
0.5 \\
0.5 \\
0.5 \\
0.5 \\
0.5 \\
0.5\end{array}$ & 1 & & & & & & & & & & & & & & & & & & & & & \\
\hline Oligocene & $62 \mathrm{R}-1,67-68$ & 870.0 & 0.5 & & & & & & & & & & & & & & & & & & & & & & \\
\hline
\end{tabular}

Dischorhabds (Pl. 2, Figs. 1-3): This type was rare, with three specimens found altogether. These specimens are very similar to one illustrated by Locker and Martini (1986, pl. 13, fig. 4) and Bukry (1979, pl. 6, fig. 14).

Unknown spicule type (Pl. 2, Figs. 12, 13): Several specimens of an unknown spicule were found. The spicule has the general morphology of a small curved oxea but with rounded terminations. To both sides of the spicule's central point are several nodes, which appear to be in a tetragonal arrangement; the nodes are short and rounded. Additional smaller nodes may occur on the spicule, and the general texture of the spicule was sometimes rough. The occurrence of five very similar specimens suggests that these are not broken fragments or the result of dissolution. No illustrations of similar spicule morphologies have been found in the literature.

\section{SILICOFLAGELLATES}

Representatives of several silicoflagellate genera were found in Sample 152-918D-13R-1, 92-94 cm. Only a single additional silicoflagellate was found in the rest of the study. 
Genus BACHMANNOCENA Locker, 1974; emend. Bukry, 1987

Bachmannocena apiculata (Schulz)

(Pl. 3, Figs. 3, 4)

Bachmannocena apiculata (Schulz), Bukry, 1987, p. 403-404

Remarks. This silicoflagellate is common in sediments of the Eocene and Oligocene and suggests that the sediments in Sample 152-918D-13R-1, 92$94 \mathrm{~cm}$ have been reworked.

\section{Genus CORBISEMA Hanna, 1928}

Corbisema hastata hastata (Lemmermann)

$$
\text { (Pl. 3, Figs. 5, 6) }
$$

Dictyocha triacantha hastata Lemmermann, 1901, p. 259, pl. 10, figs. 16, 17 Corbisema hastata hastata (Lemmermann), Bukry, 1976, p. 892, pl. 4, figs. $9-16$

Remarks. The two specimens of this taxon were distinctly arrowhead shaped and were slightly asymmetrical.

\section{Corbisema triacantha (Lemmermann)}

(Pl. 3, Fig. 2)

Corbisema apiculata (Lemmermann), Ling, 1972, p. 153, pl. 24, fig. 1

Remarks. The two specimens found of this taxon were slightly larger than typical C. triacantha.

Genus DICTYOCHA Ehrenberg, 1837

Dictyocha messanensis Haeckel (Pl. 3, Fig. 10)

Dictyocha messanensis Haeckel, in Peters (1860), p. 799-800

Remarks. This taxon has considerable variability in the shape of its basal ring, the robustness of the skeletal elements, and in the presence or absence of an apical spine. Locker and Martini (1986) and other workers divided this taxon into several subspecies and forms, but these distinctions were difficult to apply consistently, thus, this taxon was not subdivided in this study.

Genus DISTEPHANUS Stohr, 1880

Distephanus crux (Ehrenberg)

$$
\text { (Pl. 3, Figs. 7-9) }
$$

Distephanus crux crux (Ehrenberg), Bukry, 1976 [Leg 36], p. 895

Remarks. This was the most abundant silicoflagellate found in the study with a total count of 12 . Several of these were variants with longer spines than usual for the species. A lone member of this species, shown on Plate 3, Fig. 9, was found in Sample 152-918D-39R-2, 95-96 cm.; this was the only silicoflagellate in this study not found in Sample 152-918D-13R-1, 92-94 cm.

Genus NAVICULOPSIS Frenguelli, 1940

Naviculopsis constricta (Schulz)

(Pl. 3, Fig. 1)

Naviculopsis constricta (Schulz), McCartney and Wise, 1987, p. 807, pl. 5, figs. 5-8

\section{EBRIDIANS}

Several representatives of ebridians were also found in Sample 152-918D-13R-1, 92-94 cm. No ebridians were found elsewhere in the study.

Genus ADONNADONNA Gombos, 1982
Adonnadonna primadonna (Gombos)

(Pl. 4, Fig. 1)

Adonnadonna primadonna Gombos, 1982, p.446

Remarks. This very unusual and large ebridian is similar and is probably closely related to Triskelion gorgon. Both have enormous size and exceptional surface ornamentation. For further remarks see those with Triskelion gorgon.

\section{Genus AMMODOCHIUM Hovasse, 1932}

Ammodochium rectangulare (Schulz)

$$
\text { (Pl. 4, Fig. 6) }
$$

Ammodochium rectangulare (Schulz), Ling, 1971, p. 694

Genus CRANIOPSIS Hovasse ex Frenguelli, 1940

Craniopsis octo Hovasse ex Frenguelli, 1940

Craniopsis octo Hovasse ex Frenguelli, 1940, p. 92, figs. 31 a-c

Genus EBRIOPSIS Hovasse, 1932

Ebriopsis antiqua antiqua (Schulz)

Ebriopsis antiqua Schulz, 1928 (in part), p. 273-274, fig. 696

Ebriopsis antiqua antiqua (Schulz), Ling, 1977, p. 215, pl. 17-18

Genus TRISKELION Gombos, 1982

Triskelion gorgon Gombos

(P1. 4, Figs. 2-4)

Triskelion gorgon Gombos, 1982, p. 446-447

Remarks. This problematic fossil has previously been found by Gombos (1982) in the middle Eocene of the southwest Atlantic Ocean and by McCartney and Wise (1990) in Oligocene sediments from the Weddell Sea near Antarctica. The occurrence in reworked sediments off Greenland suggests that this taxon is far more widely distributed, both geologically and geographically, than its sparse literature would indicate.

\section{DISCUSSION}

This study documents primarily the occurrence of sponge spicules in Hole 918D. Sample 152-918D-13R-1, 93-94 cm, which lacked sponge spicules, was unusual in that it contained nearly all of the silicoflagellates and ebridians found in the study. The silicoflagellates and ebridians found in this sample were diverse, but include only one taxon, the silicoflagellate Dictyocha messanensis that is typically found in lower Pliocene sediments. The other taxa are reworked.

Most of the reworked taxa are of geologically long-ranging species, making the age of the source material difficult to determine precisely. The presence of the ebridian Triskelion gorgon in the sample, however, indicates an age of middle Eocene to early Oligocene. All of the silicoflagellates found in this sample, except for the single specimen of Dictyocha messanensis, could be of the same age.

The core description (Larsen, Saunders, Clift, et al., 1994) indicates that the sediment of Sample 152-918D-13R-1, 93-94 cm was moderately disturbed. This is part of lithologic Unit ID, which consists of well-lithified quartz silt with clay and dark-gray compact sediment with isolated dropstones scattered throughout. The core description does not mention turbidites in this interval, although turbidites of two types are found in lithologic Unit IB, which occurred at 71.1-236.0 mbsf.

Several other studies of the Greenland transect also found reworking during the Pliocene or Pleistocene. Pliocene sediments at Site 919 included several foraminifers that were reworked (Israelson and 
Spezzaferri, this volume), and Wei (this volume) found Cretaceous nannofossils associated with dropstones in Pleistocene sediments, which he suggests were ice-rafted detritus.

The reworked fossils of Sample 152-918D-13R-1, 93-94 cm, might also be deposited as a result of ice-rafting, but it is more difficult to explain by this mechanism the concentration of typically uncommon and giant specimens such as Triskelion gorgon. Rafting should widely disperse the reworked specimens, and it would take unusual amounts of ice-rafting to deposit such a large concentration of silicoflagellates and ebridians in this sample. We believe that the concentration of siliceous microfossils in this sample can better be explained by a turbidity current.

\section{CONCLUSIONS}

The core from Hole 918D contained siliceous sponge spicules, silicoflagellates, and ebridians. The sponge spicules were found in the middle Miocene sediments, but were generally low in absolute abundance. The lower Miocene was largely barren, as was the upper Miocene and lower Pliocene. However, in the lower Pliocene there did occur an unusual presence of silicoflagellates and ebridians in Sample 152-918D-13R-1, 93-94 cm. The core description indicates the sample was moderately reworked. This study found unusually large microfossils, including Triskelion gorgon, which suggests a turbidity current.

\section{ACKNOWLEDGMENTS}

We are grateful to Earl Oman for his slide preparation, help, and interest. We wish to thank Dr. Stuart Gelder for his assistance and technical advice. Sherwood W. Wise, Jr., and Andrew M. Gombos, Jr., provided valuable constructive comments on the manuscript. We thank the Ocean Drilling Program for providing the samples and the opportunity to conduct this study. Photographic material was contributed by the University of Maine at Presque Isle. This project, completed as an independent undergraduate research project, is Micropaleontology Undergraduate Research Lab publication No. 4.

\section{REFERENCES}

Ahlbach, W.J., and McCartney, K., 1992. Siliceous sponge spicules from Site 748. In Wise, S.W., Jr., Schlich, R., et al., Proc. ODP, Sci. Results, 120 : College Station, TX (Ocean Drilling Program), 833-837.

Bukry, D., 1976. Cenozoic silicoflagellate and coccolith stratigraphy, South Atlantic Ocean, Deep Sea Drilling Project Leg 36. In Hollister, C.D., Craddock, C., et al., Init. Repts. DSDP, 35: Washington (U.S. Govt. Printing Office), 885-917.

, 1978. Cenozoic coccolith, silicoflagellate, and diatom stratigraphy, Deep Sea Drilling Project Leg 44. In Bensen, W.E., Sheridan, R.E., et al., Init. Repts. DSDP, 44: Washington (U.S. Govt. Printing Office), $807-863$.

, 1979. Cenozoic coccolith and silicoflagellate stratigraphy, Northern Mid-Atlantic Ridge and Reykjanes Ridge, Deep Sea Drilling Project Leg 49. In Luyendyk, B.P., Cann J.R., et al., Init. Repts. DSDP, 49: Washington (U.S. Govt. Printing Office), 551-582.

1987. Eocene siliceous and calcareous phytoplankton, Deep Sea Drilling Project Leg 95. In Poag, C.W., Watts, A.B., et al., Init. Repts. DSDP, 95: Washington (U.S. Govt. Printing Office), 395-415.
Ehrenberg, C.G., 1854. Mikrogeologie: Das Erden und Felsen schaffende Wirken des unsichtbar kleines selbständigen Lebens auf der Erde: Leipzig (Leopold Voss).

Frenguelli, J., 1940. Consideraciones sobre los silicoflagelados fósiles. Rev. Mus. La Plata, Secc. Geol., 2:37-112.

Gombos, A.M., Jr., 1982. Three new and unusual genera of ebridians from the Southwest Atlantic Ocean. J. Paleontol., 56:444-448.

Hartman, W.D., 1982. Form and distribution of silica in sponges. In Simpson, T.L., and Volcani, B.E. (Eds.), Silicon and Siliceous Structures in Biological Systems: New York (Springer-Verlag), 453-491.

Ivanik, M.M., 1983. Paleogene and Neogene sponge spicules from Sites 511 512, and 513 in the South Atlantic. In Ludwig, W.J., Krasheninnikov, V. A., et al., Init. Repts. DSDP, 71 (Pt. 2): Washington (U.S. Govt. Printing Office), 933-950.

Larsen, H.C., Saunders, A.D., Clift, P.D., et al., 1994. Proc. ODP, Init. Repts., 152: College Station, TX (Ocean Drilling Program).

Lemmermann, E., 1901. Silicoflagellatae. Ber. Dtsch. Bot. Ges., 19:247-271.

Ling, H.Y., 1971. Silicoflagellates and ebridians from the Shinzan diatomaceous mudstone member of the Onnagawa Formation (Miocene), Northeast Japan. In Farinacci, A. (Ed.), Proc. 2nd Planktonic Conf. Roma. Rome (Ed. Technosci.), 689-703.

1972. Upper Cretaceous and Cenozoic silicoflagellates and ebridians. Bull Am. Paleontol., 62:135-229.

1977. Late Cenozoic silicoflagellates and ebridians from the eastern North Pacific region. In Saito, T., and Ujiie, H. (Eds.), Proc. First Int. Congr. Pacific Neogene Stratigraphy, 1:205-233.

Locker, S., and Martini, E., 1986. Silicoflagellates and some sponge spicules from the southwest Pacific, DSDP Leg 90. In Kennett, J.P., von der Borch, C.C., et al., Init. Repts. DSDP, 90: Washington (U.S. Govt. Printing Office), 887-924.

McCartney, K., 1987. Siliceous sponge spicules from Deep Sea Drilling Project Leg 93. In van Hinte, J.E., Wise, S.W., Jr., et al., Init. Repts. DSDP, 93 (Pt. 2): Washington (U.S. Govt. Printing Office), 815-824. 1990. Siliceous sponge spicules from Ocean Drilling Program Leg 113. In Barker, P.F., Kennett, J.P., et al., Proc. ODP, Sci. Results, 113: College Station, TX (Ocean Drilling Program), 963-970.

McCartney, K., and Wise, S.W., Jr., 1987. Silicoflagellates and ebridians from the New Jersey Transect, Deep Sea Drilling Project Leg 93, Sites 604 and 605. In van Hinte, J.E., Wise, S.W., Jr., et al., Init. Repts. DSDP, 93 (Pt. 2): Washington (U.S. Govt. Printing Office), 801-814.

- 1990. Cenozoic silicoflagellates and ebridians from ODP Leg 113: biostratigraphy and notes on morphologic variability. In Barker, P.F., Kennett, J.P., et al., Proc. ODP, Sci. Results, 113: College Station, TX (Ocean Drilling Program), 729-760.

Palmer, A., 1988. Paleoenvironmental significance of siliceous sponge spicules from Sites 627 and 628, Little Bahama Bank, Ocean Drilling Program Leg 101. In Austin, J.A., Jr., Schlager, W., et al., Proc. ODP, Sci. Results, 101: College Station, TX (Ocean Drilling Program), 159-168.

Peters, W., 1860. Kurzen Auszug aus einer Abhandlung des Hrn. Dr. Ernst Haeckel über neue, ledende Radiolarien des Mittelmeeres und legte die dazu gehörigen Abbildungen vor. Mber. Verh. K. Preuss. Akad. Wiss. Berlin, 794-817.

Schulz, P., 1928. Beiträge zur Kenntnis fossiler und rezenter Silicoflagellaten. Bot. Arch., 21:225-292.

Zolnik, R., McCartney, K., and White, L.D., 1992. Siliceous sponge spicules from Site 795. In Pisciotto, K.A., Ingle, J.C., Jr., von Breymann, M.T., Barron, J., et al., Proc. ODP, Sci. Results, 127/128 (Pt. 1): College Station, TX (Ocean Drilling Program), 541-544.

Date of initial receipt: 14 August 1995

Date of acceptance: 12 June 1996

Ms 152SR-216 


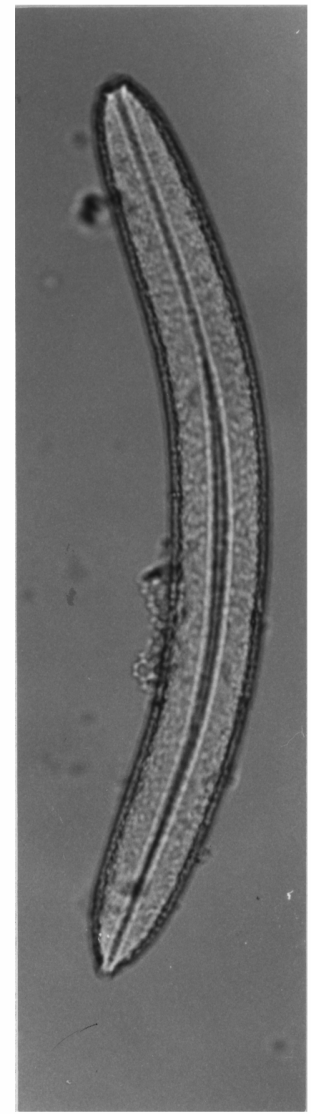

1

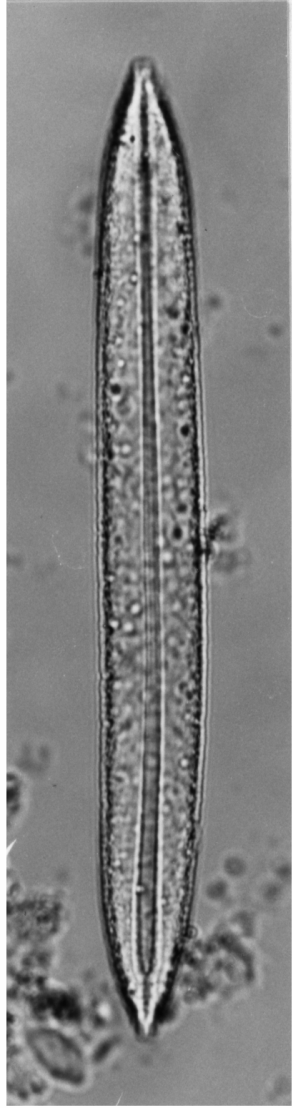

2

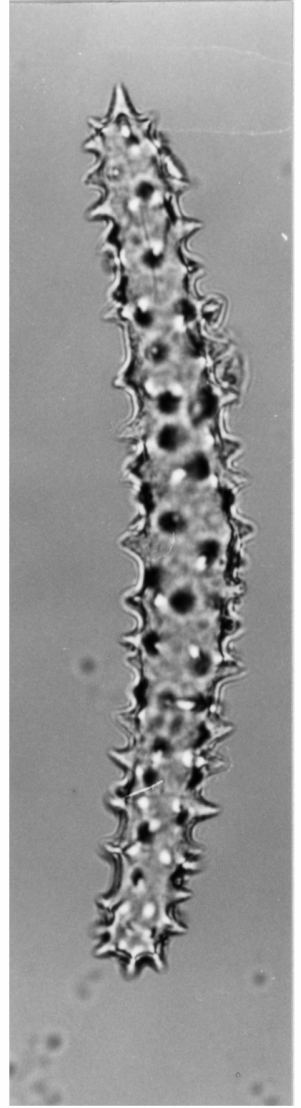

3

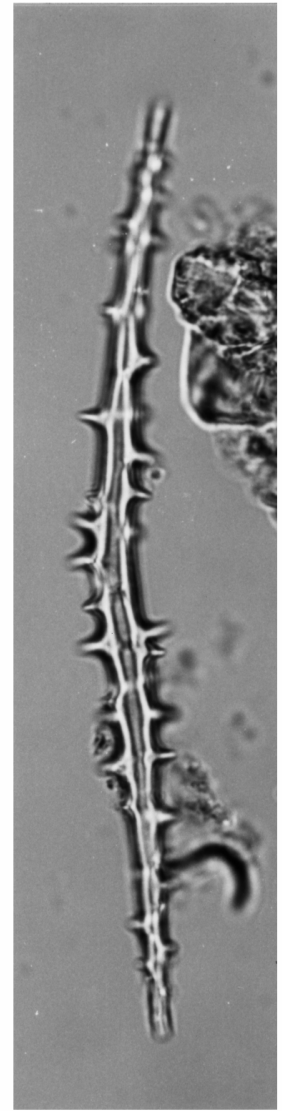

4

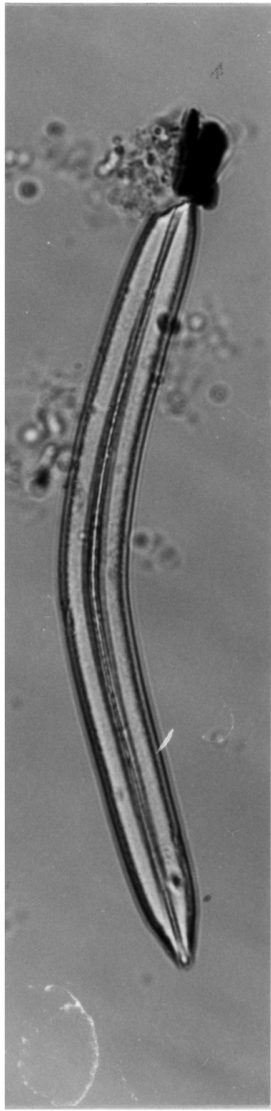

5

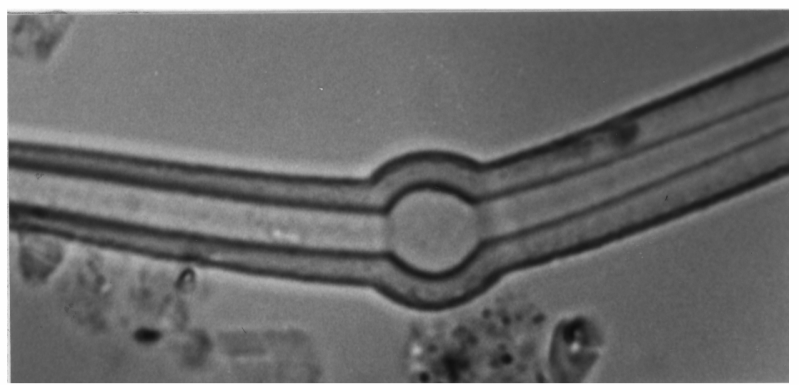

6

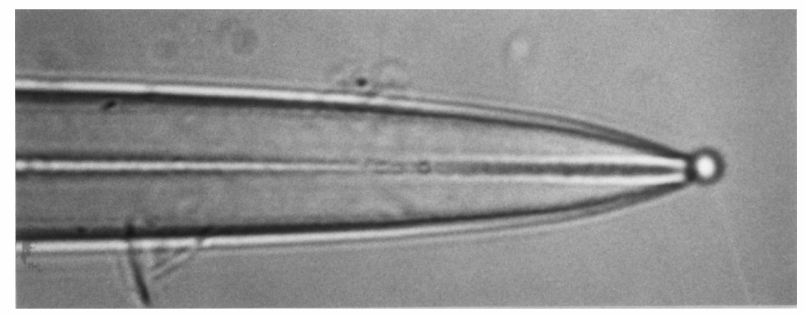
7

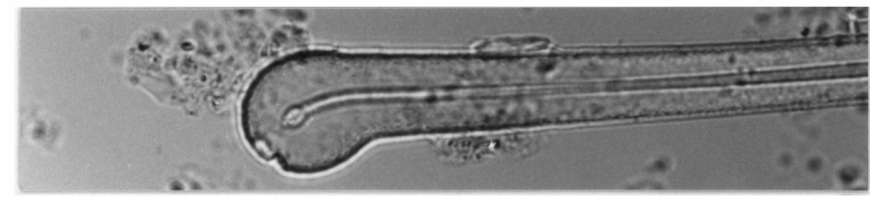

8

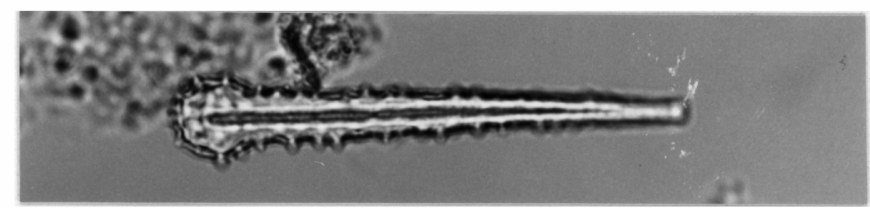

9

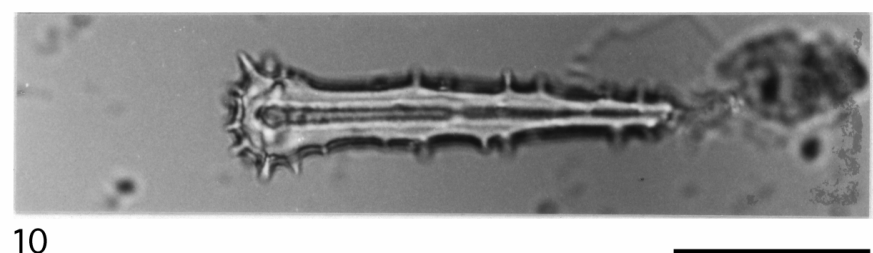

10

Plate 1. Sponge spicules from Site 918D (570x; scale bar = 35 um). 1-2. Oxea; (1) Sample 152-918D-41R-3, 120-121 cm; (2) Sample 152-918D-44R-4, 66-67 cm. 3. Acanthostrongyle; Sample 152-918D-44R-4, 66-67 cm. 4. Acanthoxea; Sample 152-918D-42R-3, 54-55 cm. 5. Oxea, bent; Sample 152-918D-44R-1, 61-63 cm. 6. Style with bulbous central region; Sample 152-918D-39R-1, 78-79 cm (1140×). 7. Oxea with bulbous tip; Sample 152-918D-39R-2, 95-96 cm (1140×). 8. Tylostyle with bent bulb; Sample 152-918D-41R-3, 120-121 cm. 9-10. Acanthotylostyles; (9) Sample 152-918D-47R-2, 66-67 cm; (10) Sample $152-918 \mathrm{D}-41 \mathrm{R}-4,109-110 \mathrm{~cm}$. 


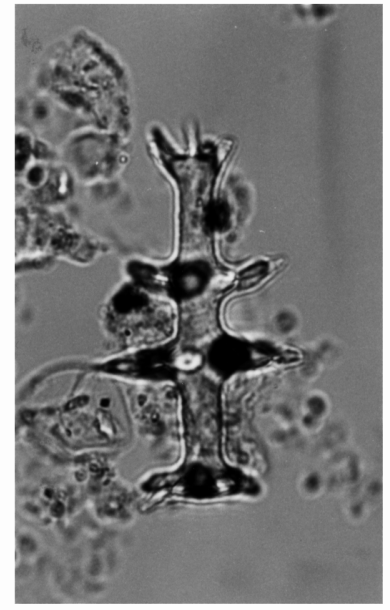

1

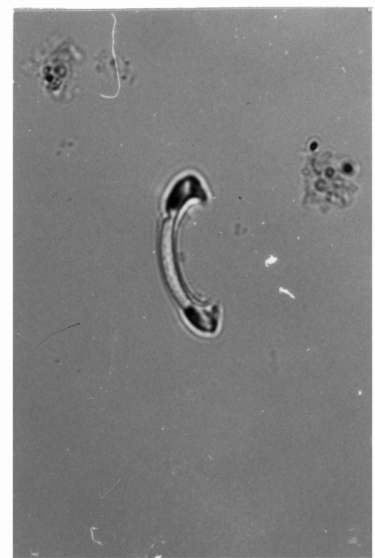

5

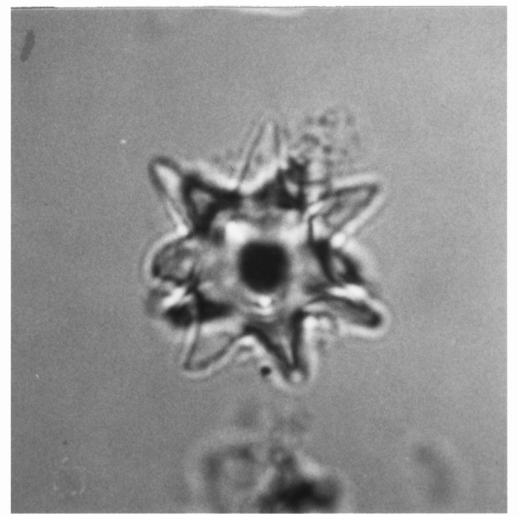

10

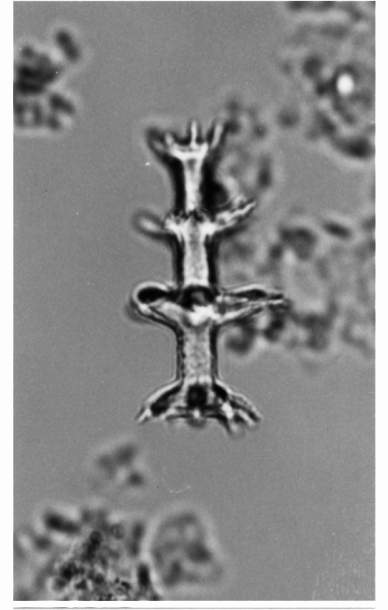

2

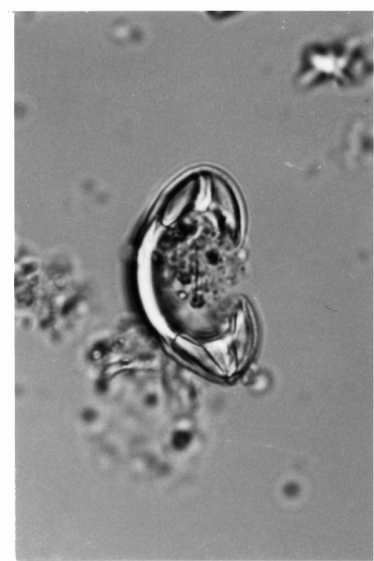

6

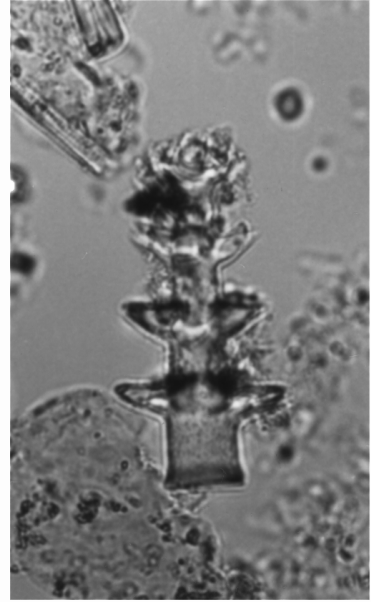

3

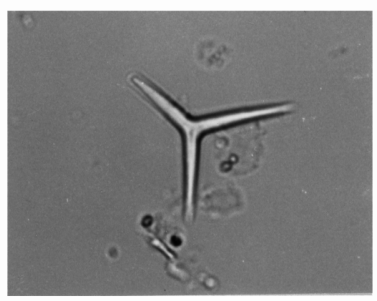

7

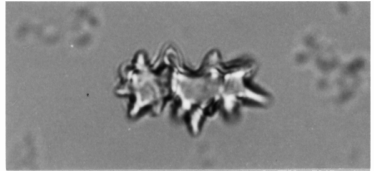

8

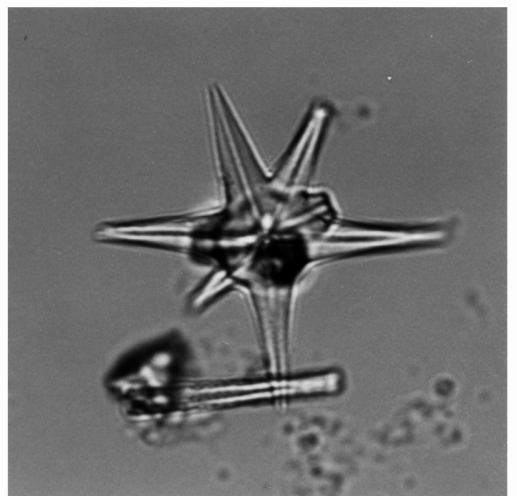

11

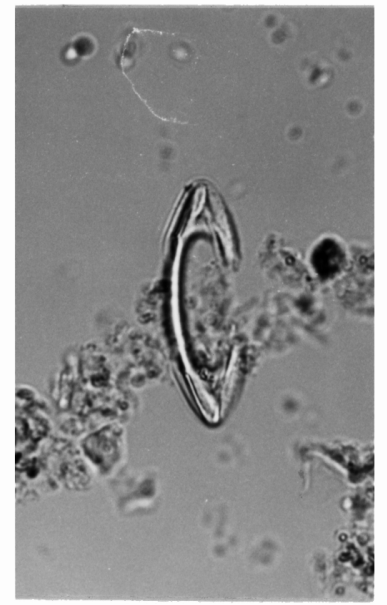

4

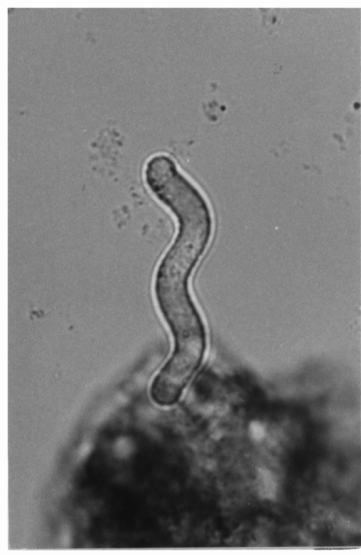

9

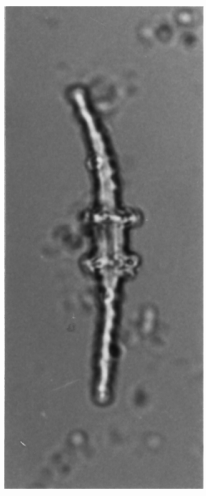

12

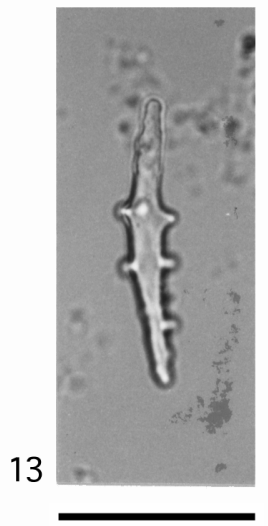

Plate 2. Sponge spicules from Site 918D (570x; scale bar $=35 \mu \mathrm{m}$.) 1-2. Discorhabds; (1) Sample 152-918D-47R-2, 66-67 cm; (2) Sample 152-918D-47R-2, 66-67 cm. 3. Discorhabd (?); Sample 152-918D-40R-5, 63-64 cm. 4-6. Isochela; (4) Sample 152-918D-42R-3, 54-55 cm; (5) Sample 152-918D-47R-2, 66$67 \mathrm{~cm}$; (6) Sample 152-918D-42R-3, 54-55 cm. 7. Triod; Sample 152-918D-43R-2, 52-53 cm. 8. Streptaster; Sample 152-918D-42R-3, 54-55 cm. 9. Sinusoidal-strongyle; Sample 152-918D-41R-4, 109-110 cm. 10. Spheraster; Sample 152-918D-39R-2, 95-96 cm. 11. Oxyaster; Sample 152-918D-47R-2, 66-67 cm. 12. Sample 152-918D-40R-4, 50-51 cm. 13. Acanthoxea(?); Sample 152-918D-41R-4, 109-110 cm. 

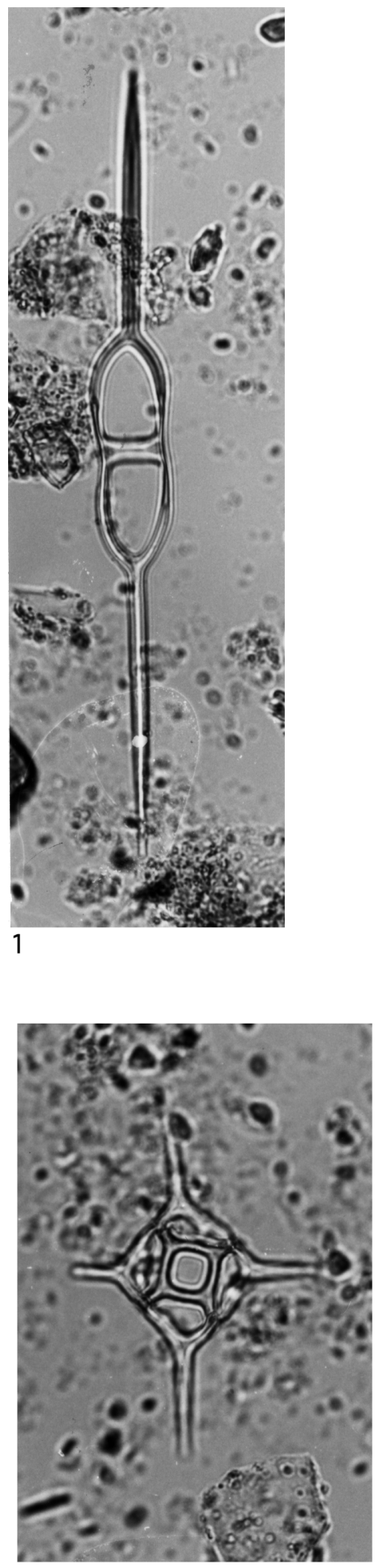

7

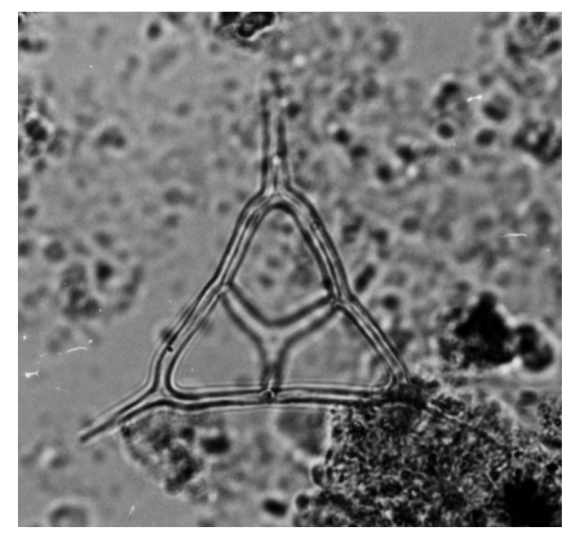

2

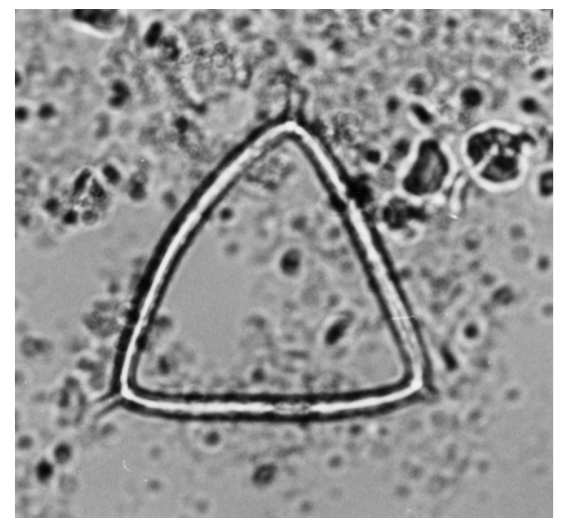

4

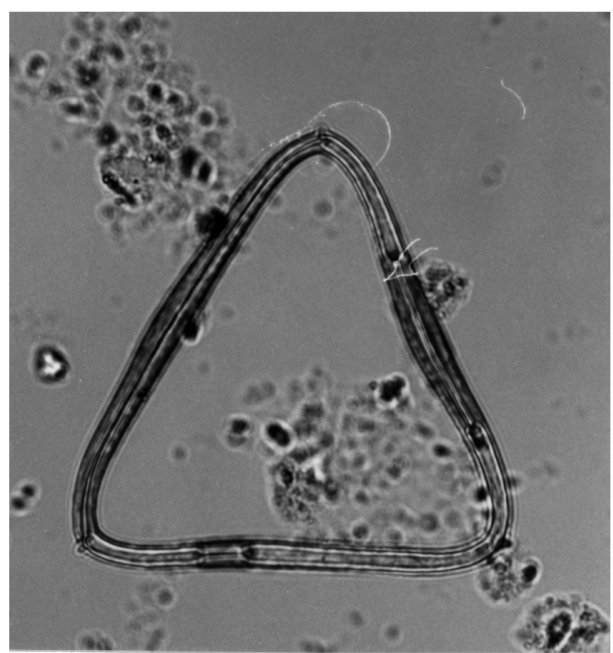

3

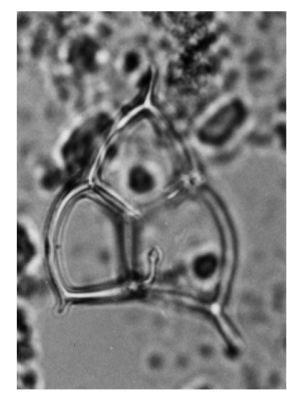

5

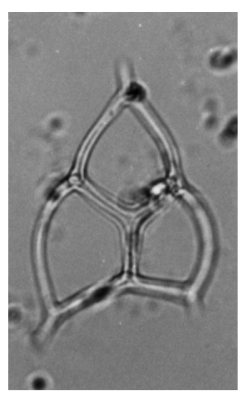

6

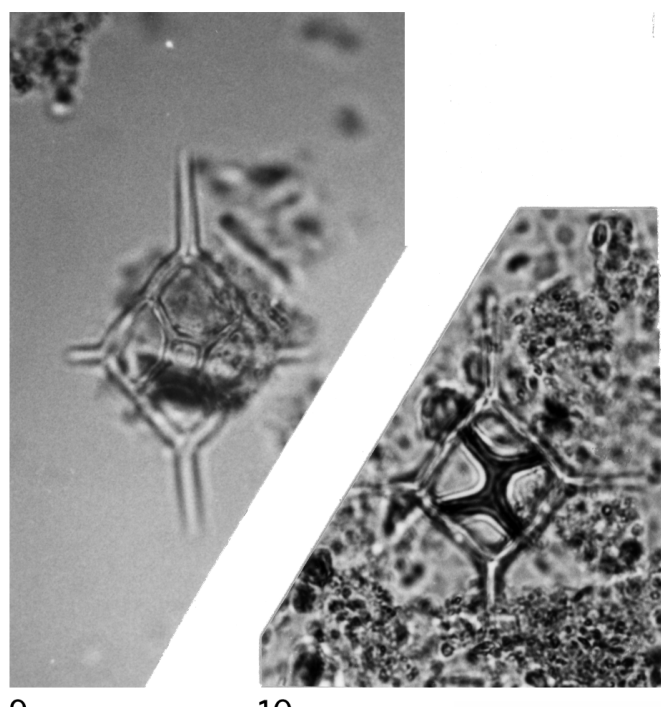

9

10

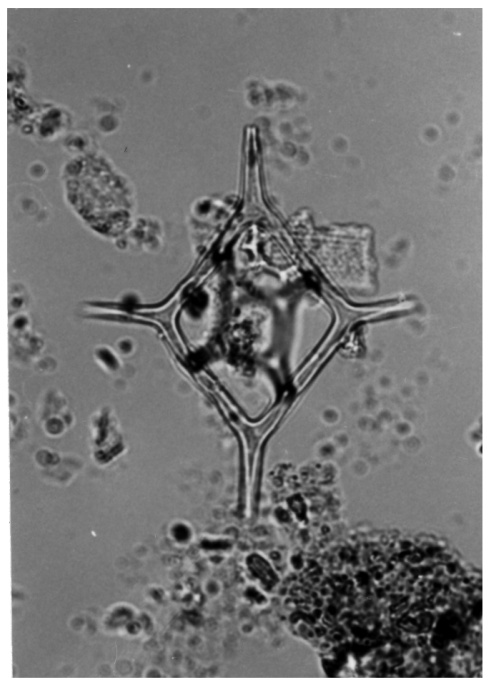

8

Plate 3. Silicoflagellates $(570 x ;$ scale bar $=35 \mu \mathrm{m})$. 1. Naviculopsis constricta (Schulz); Sample 152-918D-13R-1, 92-94 cm. 2. Corbisema triacantha $($ Lemmermann); Sample 152-918D-13R-1, 93-94 cm. 3-4. Bachmannocena apiculata (Schulz); Sample 152-918D-13R-1, 93-94 cm. 5-6. Corbisema hastata; Sample 152-918D-13R-1, 93-94 cm. 7-9. Distephanus crux (Ehrenberg); (7-8) Sample 152-918D-13R-1, 93-94 cm; (9) Sample 152-918D-39R-2, 95-96 cm. 10. Dictyocha messanensis Haeckel; Sample 152-918D-13R-1, 92-94 cm. 


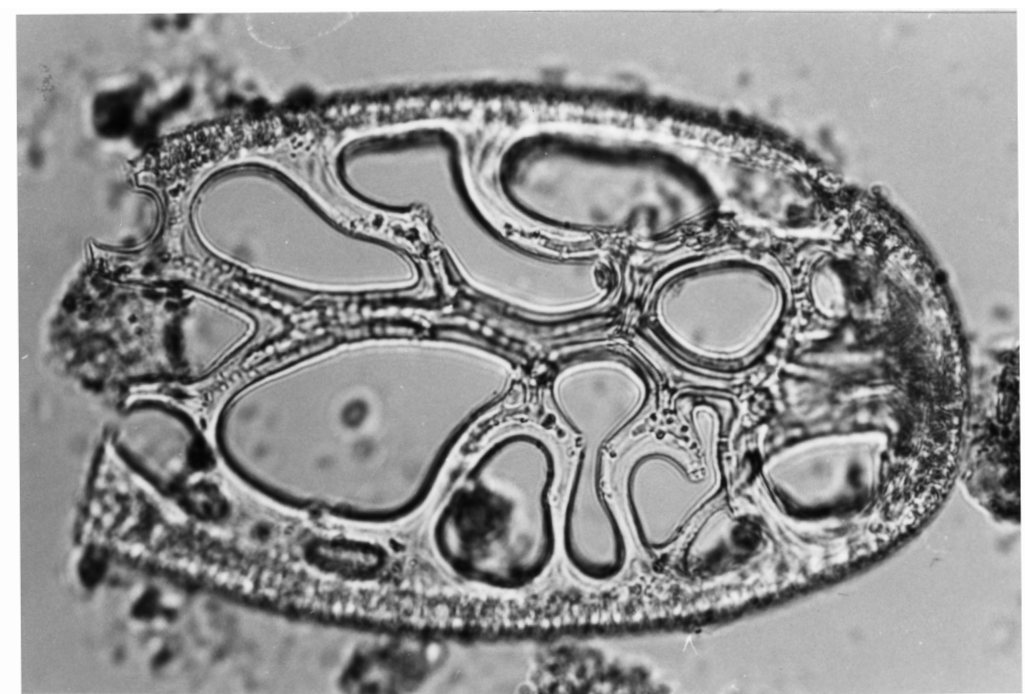

1

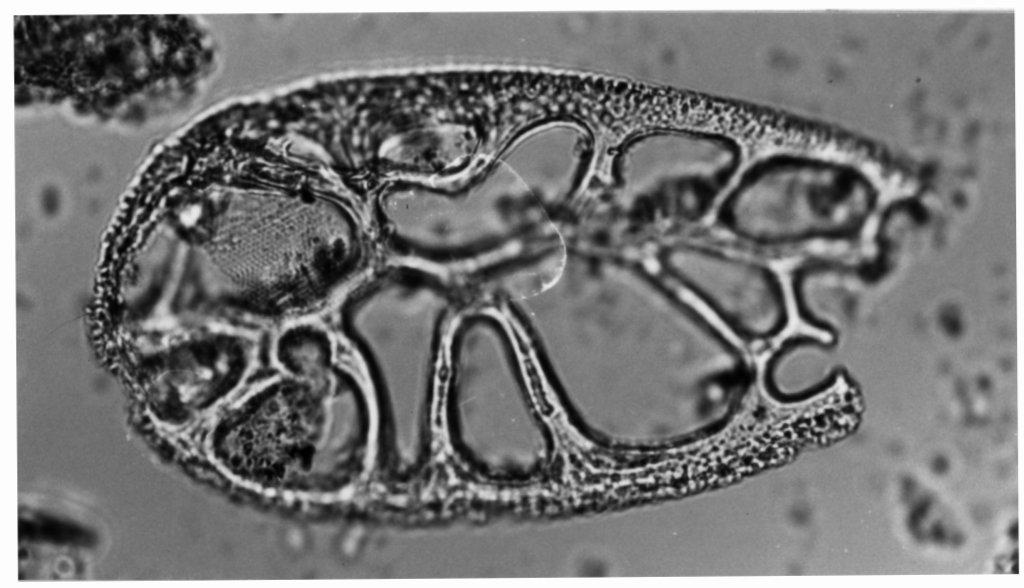

3

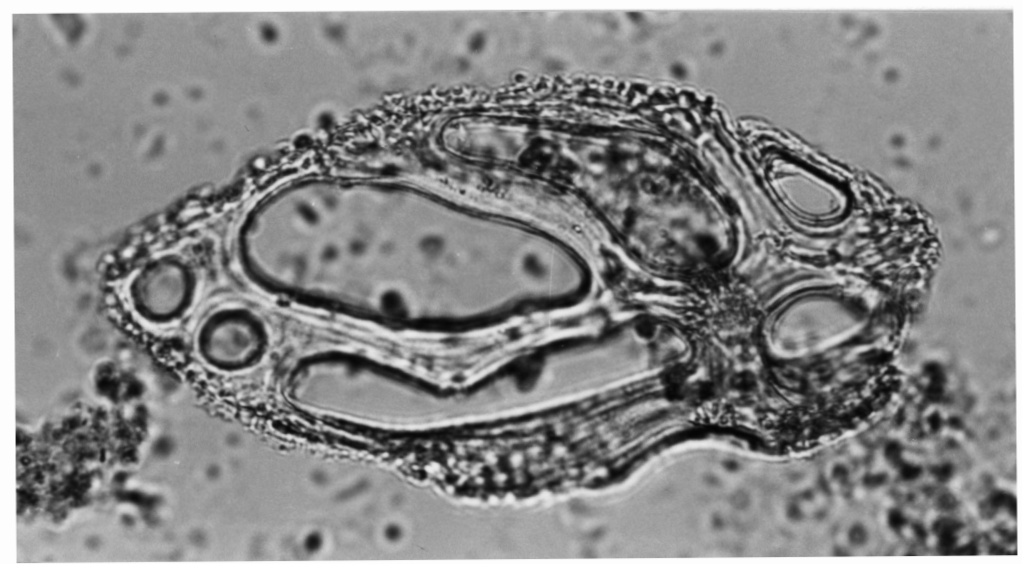

4

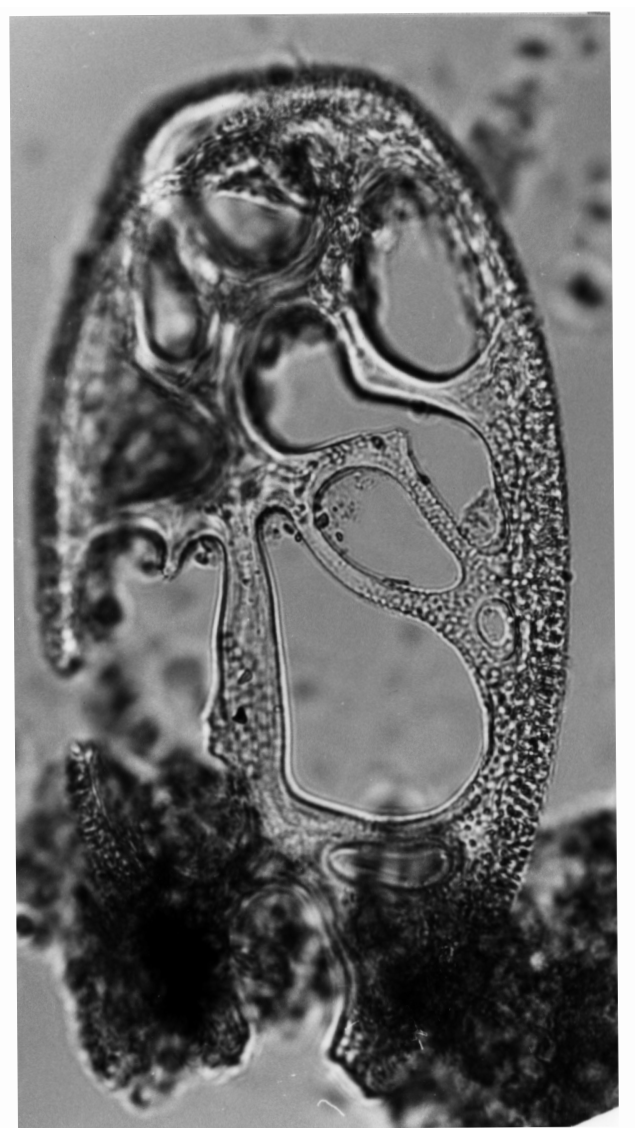

2

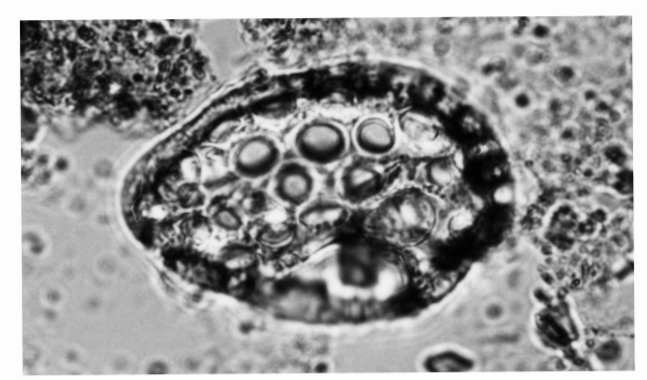

5

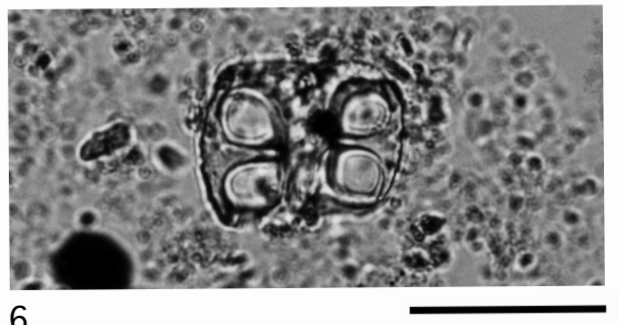

Plate 4. Ebridians $(570 \times$; scale bar $=35 \mu \mathrm{m})$. 1. Adonnadonna primadonna Gombos; Sample 152-918D-13R-1, 93-94 cm. 2-4. Triskelion gorgon Gombos; Sample 152-918D-13R-1, 93-94 cm. 5. Unknown ebridian, Sample 152-918D-13R-1, $93-94$ cm. 6. Ammodochium rectangulare (Schulz), lorica; Sample 152918D-13R-1, 93-94 cm. 